\title{
A rapid and simple method for Bacillus subtilis transformation on solid media
}

\author{
Philippe M. Hauser† and Dimitri Karamata
}

Author for correspondence: Dimitri Karamata. Tel: +41213206075. Fax: +41213206078.

Institut de Génétique et Biologie Microbiennes, Rue César-Roux 19, 1005 Lausanne, Switzerland

\begin{abstract}
Cells of Bacillus subtilis strains 168 and W23 deprived of an amino acid or a base on a given solid medium were found to develop competence. We describe a rapid and simple method of genetic transformation of this organism consisting in spreading a sample containing $1 \mu \mathrm{g}$ DNA and $10^{7}$ exponentially growing cells of an auxotrophic mutant onto plates devoid of the required amino acid or base. After overnight incubation, about 100-200 prototrophic transformants per plate were obtained, i.e. a frequency of about $10^{-5}$, as compared to $10^{-4}$ routinely obtained by the method of transformation in liquid medium with frozen competent cells. Plasmids and other chromosomal or plasmid-borne markers, which cannot be directly selected for, were transferred by congression. The dependence of the transformation efficiency on cell density, medium richness, incubation time and the nature of transforming DNA was investigated. We conclude that the development of competence accompanies amino acid or base starvation of cells under appropriate physiological conditions.
\end{abstract}

Keywords: Bacillus subtilis, transformation on plates, competence, plasmid

\section{INTRODUCTION}

Bacillus subtilis is a Gram-positive bacterium capable of developing competence and undergoing DNA-mediated transformation (Dubnau, 1991). Spizizen (1958) and Anagnostopoulos \& Spizizen (1961) described the conditions under which cells growing in liquid medium attain the state of competence allowing uptake of donor DNA and transformation. This method, which results in relatively high transformation frequencies with appropriate strains, has undergone a few minor modifications but is still in use. The process of obtaining competent cells is rather delicate, and takes 5-6 h. Therefore, more recently, competent cells were frozen and then thawed before use. This was accompanied by a 5-10-fold lower transformation efficiency. To simplify the preparation of competent cells, several methods have been proposed. Ephrati-Elizur (1965) described a method involving $60 \mathrm{~min}$ growth followed by $30 \mathrm{~min}$ exposure to transforming DNA. Transformants were obtained at a frequency of $10^{-3}$ to $10^{-4}$. However, to obtain reproducible results, the overnight culture must be inoculated with a

†Present address: Sir William Dunn School of Pathology, Chemical Pathology Unit, University of Oxford, South Parks Road, Oxford OX1 3RE, UK. defined number of spores. Thus, the method requires preliminary preparation, purification and counting of spores. Tanooka (1973) proposed spreading a mixture of germinating spores of an auxotrophic strain and wild-type DNA onto plates which were only partly supplemented for the recipient's requirement. Development of competence occurred on the plates and transformants arose at a frequency about 100 -fold lower than that obtained in parallel crosses performed by the method of Anagnostopoulos \& Spizizen (1961). However, the absolute frequency of transformation was not calculated. In addition, the method requires preliminary determination of the concentration of the limiting amino acid in the plates. Recently, Kunst et al. (1994) described a protocol in which competence was attained $60 \mathrm{~min}$ after the end of the exponential phase in a minimal medium containing glutamate and casein hydrolysate. Nevertheless, although this method is much simpler than that of Anagnostopoulos \& Spizizen (1961), it still takes several hours. Galizzi et al. (1976), and subsequently Hahn et al. (1987), achieved transformation by simply replicating fresh colonies onto selective plates seeded with donor DNA. However, this method, used for screening purposes, was not quantitative.

In this paper we describe a simple and rapid transformation procedure on solid media which yields about 
100 transformants per plate, i.e. a transformation frequency of about $10^{-5}$.

\section{METHODS}

Strains and media. B. subtilis strains are listed in Table 1. SR is Schaeffer's rich sporulation medium (Schaeffer et al., 1965). LA is solid L medium (Karamata \& Gross, 1970), containing, per litre: tryptone (Difco) $10 \mathrm{~g}$, yeast extract (Difco) $5 \mathrm{~g}, \mathrm{NaCl} 10 \mathrm{~g}$, agar (Gibco) $12 \mathrm{~g}$, thymidine $20 \mathrm{mg} ; \mathrm{pH} 7 \cdot 0$. TS medium (Karamata \& Gross, 1970) is Spizizen minimal medium, containing, per litre: $\left(\mathrm{NH}_{4}\right)_{2} \mathrm{SO}_{4} 2 \mathrm{~g}, \mathrm{~K}_{2} \mathrm{HPO}_{4} 14 \mathrm{~g}, \mathrm{KH}_{2} \mathrm{PO}_{4}$ $6 \mathrm{~g}$, trisodium citrate dihydrate $1 \mathrm{~g}, \mathrm{MgSO}_{4} .7 \mathrm{H}_{2} \mathrm{O} 0.2 \mathrm{~g}$, glucose $5 \mathrm{~g}$ and supplemented with $\mathrm{MnSO}_{4} 0.85 \mathrm{mg}$, sodium glutamate $5 \mathrm{~g}$ and yeast extract (Difco) $0.01 \mathrm{~g}$. When required, $20 \mu \mathrm{g} \mathrm{ml}^{-1}$ of amino acids and $50 \mu \mathrm{g} \mathrm{ml}^{-1}$ of bases were added to this medium.

DNA preparation. Chromosomal DNA was prepared according to Marmur (1961), and purified by centrifugation on $\mathrm{CsCl}$ density gradients (Maniatis et al., 1982). Plasmid and bacteriophage DNA were prepared as described by Del Sal et al. (1988) and Grossberger (1987), respectively.

Transformation on plates. Cells grown on LA plates or spores, generated at $30^{\circ} \mathrm{C}$ on SR medium slants or plates, were spread onto LA plates and grown overnight at $30^{\circ} \mathrm{C}$. The cells thus obtained were resuspended in sterile double-distilled water and their concentration determined either by counting or by nephelometric density (ND) measurements on an appropriate dilution. ND was measured on a Unigalvo (Corning-EEL) nephelometer. For cells originating from fresh colonies on LA plates, an ND reading of 100 corresponds to about $1 \times 10^{8}$ c.f.u. and $1.5 \times 10^{8}$ cells per ml. A $0.1-0.5 \mathrm{ml}$ sample containing $10^{7}$ cells was mixed with 3-40 $\mu$ l of a DNA preparation (a total of 0.6-3 $\mu \mathrm{g}$ DNA); the mixture was spread immediately on appropriately supplemented TS plates $(8.5 \mathrm{~cm}$ diameter) and incubated at $37^{\circ} \mathrm{C}$.

Table 1. B. subtilis strains

\begin{tabular}{|c|c|c|}
\hline Strain & Genotype or description & $\begin{array}{l}\text { Reference or } \\
\text { remarks }\end{array}$ \\
\hline L1440 & Prototroph & $\begin{array}{l}\text { Mauël \& Karamata } \\
\text { (1984) }\end{array}$ \\
\hline 168 & $\operatorname{trp} C 2$ & Laboratory stock \\
\hline GSY1127 & bisH2 ilvC1/ilv $C^{+}$ & $\begin{array}{c}\text { Anagnostopoulos \& } \\
\text { Trowsdale (1976); } \\
\text { merodiploid strain }\end{array}$ \\
\hline M22 & pur $A 16$ leu $A 8$ metB5 ilv $A 1$ & $\begin{array}{l}\text { Karamata \& Gross } \\
(1970)\end{array}$ \\
\hline L5256 & fla $A 15$ pur $A 16$ ilv $A 1$ & $\begin{array}{l}\text { Pooley \& Karamata } \\
\text { (1984) }\end{array}$ \\
\hline Ni15 & $\begin{array}{l}\text { fla } A 15 \text { trpC2 tby } A 1 \text { thy } B 1 \\
\text { xin- } 15\end{array}$ & Pooley (1976) \\
\hline $2 \mathrm{~A} 1$ & $t b r$ & $\begin{array}{l}\text { W23 strain; BGSC* } \\
\text { original code SB } 623\end{array}$ \\
\hline $2 \mathrm{~A} 2$ & prototroph & $\begin{array}{l}\text { W23 strain; BGSC* } \\
\text { original code WB } 672\end{array}$ \\
\hline
\end{tabular}

* Bacillus Genetic Stock Center, Ohio State University, Columbus, Ohio, USA.
Transformation in liquid medium. Competent cells were obtained according to the protocol of Pooley \& Karamata (1984). They were centrifuged at $4{ }^{\circ} \mathrm{C}$, resuspended at $0{ }^{\circ} \mathrm{C}$ in one-tenth of the initial volume of the supernatant, supplemented with $0.5 \%$ glucose and $15 \%(\mathrm{v} / \mathrm{v})$ glycerol, frozen in liquid nitrogen and stored at $-80^{\circ} \mathrm{C}$. For transformation, $0 \cdot 1 \mathrm{ml}$ cells were thawed at $37^{\circ} \mathrm{C}$, added to a tube containing $0.1 \mathrm{ml}$ supplemented transformation medium and $0 \cdot 1 \mathrm{ml}$ DNA (final concentration of 3-5 $\mu \mathrm{g} \mathrm{ml}^{-1}$ ), and incubated for $60 \mathrm{~min}$ at $37^{\circ} \mathrm{C}$ with shaking. They were then diluted in nonsupplemented transformation medium, plated onto appropriate TS plates and incubated overnight at $37^{\circ} \mathrm{C}$.

\section{RESULTS AND DISCUSSION}

To achieve transformation from auxotrophy to prototrophy cells of $B$. subtilis strains 168 and W23, a mixture of donor DNA and recipient cells was spread on solid medium (TS) using the following protocol: (i) Cells from an overnight culture on rich medium (LA) were resuspended in double-distilled water and supplemented by donor DNA of different origin and degree of purity (plasmid, purified recombinant phage DNA, lysate of Escherichia coli infected by recombinant phage or chromosomal DNA, either purified or not purified on a $\mathrm{CsCl}$ density gradient). (ii) The $0 \cdot 1-0.5 \mathrm{ml}$ samples of the mixture spread on the plates contained a total of $10^{7}$ cells and $1-3 \mu \mathrm{g}$ of DNA. (iii) Limited growth was allowed before the beginning of starvation for one of the recipient's requirements. Following $24 \mathrm{~h}$ incubation, about 100-200 colonies of prototrophic transformants per plate are obtained for all recipient strains and auxotrophic markers tested, i.e. about $10^{-5}$ transformants per cells initially present on the plate (Table 2 ). For strain 168 , this frequency is one order of magnitude lower than that which we routinely obtain with thawed competent cells. However, strain W23 is not transformable in liquid medium with the standard protocol. That the prototrophic colonies were transformants was indicated by their absence (i) when DNA was treated with DNase prior to mixing with cells, and (ii) when both the donor and the recipient strain carried the same relevant auxotrophic mutation. The size of recombinant colonies, relatively small when compared to those obtained in parallel crosses performed by standard methods, suggests that competence development and DNA uptake took place on the plate after several hours of incubation.

Under the experimental conditions used, i.e. spreading $1 \mu \mathrm{g}$ of DNA per plate $\left(5675 \mathrm{~mm}^{2}\right)$ which, for purified DNA, corresponds on the average to about $4 \times 10^{10}$ molecules of $1.5 \times 10^{7} \mathrm{Da}$, we can calculate that each cell (about $1.2 \mu \mathrm{m}^{2}$ ) is in contact with about 50 molecules of DNA. That this corresponds to a saturating DNA concentration is demonstrated by a congression of about $10 \%$ between unlinked markers pur $A 16$ and metB 5 or ilv $A 1$ even with $0.6 \mu \mathrm{g}$ DNA per plate, i.e. a co-transfer comparable to that obtained in liquid medium at saturating DNA concentrations (data not presented).

Occurrence of high co-transfer during transformation on plates allowed the introduction, by congression, of plasmids carrying markers unsuitable for direct selection 
Table 2. Transformation of $B$. subtilis on solid medium

Cells grown overnight on LA were resuspended in sterile water, mixed with transforming DNA, plated onto TS selective medium and incubated at $37^{\circ} \mathrm{C}$. Except W23 strains $2 \mathrm{~A} 1$ and $2 \mathrm{~A} 2$, all strains are 168 derivatives.

\begin{tabular}{|c|c|c|c|c|c|}
\hline \multirow[t]{3}{*}{ Donor* } & \multirow[t]{3}{*}{ Recipient $\dagger$} & \multirow{3}{*}{$\begin{array}{l}\text { Selected } \\
\text { marker } \ddagger\end{array}$} & \multirow{3}{*}{$\begin{array}{c}\text { No. of cells } \\
\text { per plate }\end{array}$} & \multicolumn{2}{|c|}{ Transformants per cell plated } \\
\hline & & & & \multicolumn{2}{|c|}{ Incubation time $₫:$} \\
\hline & & & & $24 \mathrm{~h}$ & $48 \mathrm{~h}$ \\
\hline \multirow[t]{5}{*}{ L1440 } & \multirow[t]{5}{*}{ M22 len $A 8$} & \multirow[t]{5}{*}{$\mathrm{Leu}^{+}$} & $10^{8}$ & $5 \times 10^{-6}$ & $5 \times 10^{-6}$ \\
\hline & & & $10^{7}$ & $1 \times 10^{-5}$ & $3 \times 10^{-5}$ \\
\hline & & & $10^{6}$ & $1 \times 10^{-5}$ & $4 \times 10^{-5}$ \\
\hline & & & $10^{5}$ & 0 & $2 \times 10^{-4}$ \\
\hline & & & $10^{4}$ & 0 & $3 \times 10^{-3}$ \\
\hline \multirow[t]{6}{*}{ GSY1127\| } & \multirow[t]{6}{*}{ L5256 ilv $A 1$} & \multirow[t]{6}{*}{$\mathrm{Ilv}^{+}$} & $10^{8}$ & $5 \times 10^{-6}$ & $5 \times 10^{-6}$ \\
\hline & & & $10^{7}$ & $2 \times 10^{-5}$ & $2 \times 10^{-5}$ \\
\hline & & & $10^{6}$ & $1 \times 10^{-5}$ & $3 \times 10^{-5}$ \\
\hline & & & $3 \times 10^{5}$ & $3 \times 10^{-5}$ & $1 \times 10^{-4}$ \\
\hline & & & $10^{5}$ & $3 \times 10^{-5}$ & $7 \times 10^{-4}$ \\
\hline & & & $3 \times 10^{4}$ & $2 \times 10^{-5}$ & $5 \times 10^{-3}$ \\
\hline \multirow[t]{3}{*}{ L 1440} & \multirow[t]{3}{*}{$168 \operatorname{trp} C 2$} & \multirow[t]{3}{*}{$\operatorname{Trp}^{+}$} & $10^{8}$ & $3 \times 10^{-6}$ & $3 \times 10^{-6}$ \\
\hline & & & $10^{7}$ & $5 \times 10^{-6}$ & $5 \times 10^{-6}$ \\
\hline & & & $10^{6}$ & $3 \times 10^{-6}$ & $3 \times 10^{-6}$ \\
\hline $2 \AA 2$ & $2 \mathrm{~A} 1 \mathrm{thr}$ & $\mathrm{Thr}^{+}$ & $10^{7}$ & $2 \times 10^{-5}$ & $2 \times 10^{-5}$ \\
\hline
\end{tabular}

* $3 \mu \mathrm{g}$ of $\mathrm{CsCl}$ purified DNA per plate was used except in the $\mathrm{L} 1440 \times 168$ cross, where $2 \mu \mathrm{g}$ was added. † Relevant markers only are shown.

$\ddagger$ The reversion frequency of the $\operatorname{leu} A 8$ marker was about $6 \times 10^{-8}$, while those of $i l v A 1$ and $\operatorname{tr} p C 2$ were below $10^{-8}$.

$\$$ The same plates were examined at 24 and $48 \mathrm{~h}$.

\| The marker ilvA1 is not duplicated in the merodiploid strain GSY1127.

by this method. A sample containing $2 \cdot 4 \mu \mathrm{g}$ of strain 168 Ilv $\mathrm{A}^{+}$chromosomal DNA and $0.15 \mu \mathrm{g}$ of concatemers of plasmid pMTL500C was added to M22 ilv A1 recipient cells and spread on a TS plate. Plasmid pMTL500C, a replicative plasmid conferring chloramphenicol resistance, was constructed by N.P. Minton, Centre for Applied Microbiology, Porton Down, UK, and provided by M. Young, Aberystwyth, UK. About $20 \%$ of selected $\mathrm{IlvA}^{+}$transformants were resistant to $5 \mu \mathrm{g}$ chloramphenicol ml $l^{-1}$. Ligase treatment of the plasmid, leading to concatamer formation, greatly increased the frequency of transformation (data not presented), in agreement with previous observations showing that transfer of plasmid DNA requires a multimeric form (Canosi et al., 1978; Mottes et al., 1979). Integration into the chromosome of non-replicative plasmids, introduced by congression, occurred at a frequency of about $1 \%$ among the selected transformants (data not presented). This relatively low efficiency may be related to the size of the chromosomal DNA insert and thus the probability of plasmid insertion into the chromosome.

To characterize some of the factors relevant for plate transformation efficiency, the incubation time and the medium composition were varied. At cell densities of less than $10^{8}$ per plate, an additional $24 \mathrm{~h}$ incubation of recipients M22 and L5256 yielded many more transformant colonies (Table 2). The frequency of these late transformants increased with a decreasing number of cells initially spread on the plate, reaching nearly $10^{-2}$ transformants for an initial density of $10^{4}$ cells per plate. This observation could be interpreted as indicating the presence of a limiting factor, which is consumed at a rate hand in hand with the number of cells initially spread on the plate. Exhaustion of this factor would be a prerequisite for the development of competence. To test this possibility, we prepared plates with media of different 'richness' (Table 3). Relatively few transformants were obtained on TS plates devoid of yeast extract, which strongly suggests that the latter component corresponds to the limiting factor. However, despite the fact that transformation efficiency and yeast extract concentration went hand in hand, we do not recommend concentrations of yeast extract as high as $0.05 \mathrm{~g} \mathrm{l}^{-1}$ since they result in too heavy a lawn due to residual growth. The appearance of transformants in the absence of yeast extract but in the presence of glutamate suggests that the latter compound does play a role in competence development. Incidentally, Kunst et al. (1994) recently showed that glutamate stimulates the expression of competence genes. In con- 
Table 3. Effect of medium richness on transformation efficiency

The medium richness of the TS plates was determined by yeast extract and glutamate concentrations.

\begin{tabular}{|lcc|}
\hline $\begin{array}{l}\text { Yeast extract } \\
\left(\mathrm{g}^{\mathbf{1}} \mathbf{)}\right.\end{array}$ & $\begin{array}{c}\text { Glutamate } \\
\mathbf{( \% )}\end{array}$ & $\begin{array}{c}\text { Relative } \\
\text { transformation } \\
\text { frequency }\end{array}$ \\
\hline $0 \cdot 01^{*}$ & $0 \cdot 5^{*}$ & 1 \\
$0 \cdot 05$ & $0 \cdot 5$ & $5-10$ \\
0 & $0 \cdot 5$ & $0 \cdot 3$ \\
0 & 0 & 0 \\
\hline
\end{tabular}

* The conventional TS medium (see Methods).

clusion, preliminary observation of competence development as a function of time and residual growth suggest that the key steps are the establishment of proper physiological conditions for colony growth, followed by amino acid or base starvation, while glutamate seems to act as an effector. Growth and starvation conditions on plates might well, to some extent, be related to those encountered in natural environments which were shown to be appropriate for efficient natural transformation (Graham \& Istock, 1978; Lorenz et al., 1988).

The method described was simplified so as to allow extensive screening and strain constructions. To that end, donor DNA was spotted onto plates previously seeded with cells, either resuspended in distilled water (see Methods) or directly spread onto plates. The occurrence of transformation as well as congression was illustrated by spotting onto the non-motile strain L5256 ilv A1 fla A15 $10 \mu \mathrm{l}$ of a mixture of diluted chromosomal DNA (1 $\mu \mathrm{g}$ $\mathrm{ml}^{-1}$ ) obtained from strain Ni15 flaA15 $\mathrm{IlvA}^{+}$and a saturating concentration of recombinant phage $\lambda U F 7$ DNA, which contains part of the fla $A$ operon (Albertini et al., 1991; Hauser et al., 1991). About $50 \%$ of selected IlvA ${ }^{+}$transformants were found to be motile, due to correction of the unlinked fla $A 15$ mutation.

In conclusion, plate transformation offers a rapid and simple method for the following applications: (i) screening of gene libraries by spotting DNA preparations onto plates and identifying the relevant marker by direct or indirect selection, (ii) simultaneous construction of a series of strains through back-crossing and congression, (iii) measurement of co-transfer and recombination indexes, and (iv) introduction of replicative plasmids and, at a rather low frequency, integration into the chromosome of plasmids with relevant inserts, by congression with reference DNA able to correct the auxotrophic mutation responsible for the development of competence on plates.

\section{ACKNOWLEDGEMENTS}

We thank the Foundation for the 450th Anniversary of the University of Lausanne for supporting the presentation of a preliminary report of this work at the Seventh International
Conference on Bacillus, Paris, France, 1993. Our thanks go to the Bacillus Genetic Stock Center (Ohio State University) for providing $B$. subtilis $\mathrm{W} 23$ strains.

\section{REFERENCES}

Albertini, A. M., Caramori, T., Crabb, W. D., Scoffone, F. \& Galizzi, A. (1991). The fla $A$ locus of Bacillus subtilis is part of a large operon coding for flagellar structures, motility functions, and an ATPaselike polypeptide. J Bacteriol 173, 3573-3579.

Anagnostopoulos, C. \& Spizizen, J. (1961). Requirements for transformation in Bacillus subtilis. J Bacteriol 81, 741-746.

Anagnostopoulos, C. \& Trowsdale, J. (1976). Production of merodiploid clones in Bacillus subtilis. In Microbiology - 1976, pp. 44-57. Edited by D. Schlessinger. Washington, DC: American Society for Microbiology.

Canosi, U., Morelli, G. \& Trautner, T. A. (1978). The relationship between molecular structure and transformation efficiency of some $S$. aureus plasmids isolated from B. subtilis. Mol \& Gen Genet 166, 259-267.

Del Sal, G., Manfioletti, G. \& Schneider, C. (1988). A one-tube plasmid DNA minipreparation suitable for sequencing. Nucleic Acids Res 16, 9878.

Dubnau, D. (1991). Genetic competence in Bacillus subtilis. Microbiol Rev 55, 395.

Ephrati-Elizur, E. (1965). Development of competence for transformation in a overnight culture of germinating spores of Bacillus subtilis. J Bacteriol 90, 550-551.

Galizzi, A., Siccardi, A. G., Mazza, G., Canosi, U. \& Polsinelli, M. (1976). A recombination test to classify mutants of Bacillus subtilis of identical phenotype. Genet Res 27, 47-58.

Graham, J. B. \& Istock, C. A. (1978). Genetic exchange in Bacillus subtilis in soil. Mol \& Gen Genet 166, 287-290.

Grossberger, D. (1987). Minipreps of DNA from bacteriophage lambda. Nucleic Acids Res 15, 6737.

Hahn, J., Albano, M. \& Dubnau, D. (1987). Isolation and characterization of Tn917lac-generated competence mutants of Bacillus subtilis. J Bacteriol 169, 3104-3109.

Hauser, P. M., Crabb, W. D., Fiora, M. G., Scoffone, F. \& Galizzi, A. (1991). Genetic analysis of the flaA locus of Bacillus subtilis. $J$ Bacteriol 173, 3580-3583.

Karamata, D. \& Gross, J. D. (1970). Isolation and genetic analysis of temperature-sensitive mutants of $B$. subtilis defective in DNA synthesis. Mol \& Gen Genet 108, 277-287.

Kunst, F., Msadek, T. \& Rapoport, G. (1994). Signal transduction network controlling degradative enzyme synthesis and competence in Bacillus subtilis. In Regulation of Bacterial Differentiation, pp. 1-19. Edited by P. J. Piggot, P. Youngman \& C. P. Moran (in press).

Lorenz, M. G., Aardema, B. W. \& Wackernagel, W. (1988). Highly efficient genetic transformation of Bacillus subtilis attached to sand grains. J Gen Microbiol 134, 107-112.

Maniatis, T., Fritsch, E. F. \& Sambrook, J. (1982). Molecular Cloning: a Laboratory Manual. Cold Spring Harbor, NY: Cold Spring Harbor Laboratory.

Marmur, J. (1961). A procedure for the isolation of deoxyribonucleic acid from microorganisms. $J$ Mol Biol 3, 208-218.

Mauël, C. \& Karamata, D. (1984). Characterisation of proteins induced by mitomycin $C$ treatment of Bacillus subtilis. J Virol 49, $806-812$.

Mottes, M., Grandi, G. \& Sgaramella, V. (1979). Different specific activities of the monomeric and oligomeric forms of plasmid DNA 
in transformation of B. subtilis and E. coli. Mol \& Gen Genet 174, $281-286$.

Pooley, H. M. (1976). Turnover and spreading of old wall during surface growth of Bacillus subtilis. J Bacteriol 125, 1127-1138.

Pooley, H. M. \& Karamata, D. (1984). Genetic analysis of autolysindeficient and flagellaless mutants of Bacillus subtilis. J Bacteriol 160, 1123-1129.

Schaeffer, P., Millet, J. \& Aubert, J. P. (1965). Catabolic repression of bacterial sporulation. Proc Natl Acad Sci USA 54, 704-711.
Spizizen, J. (1958). Transformation of biochemically deficient strains of Bacillus subtilis by deoxyribonucleate. Proc Natl Acad Sci US A 44, 1072-1078.

Tanooka, H. (1973). Transformation of germinated spores of Bacillus subtilis on agar plates. J Bacteriol 114, 445-447.

Received 4 October 1993; revised 29 January 1994; accepted 2 February 1994. 